\title{
ẢNH HƯởNG CỦA CHİ TH!̣ 16 ĐẾN NỀN KINH TẾ VIỆT NAM
}

\author{
Nguyễn An Bình, Nguyễn Đặng Linh Chi, Vũ Ánh Tuyết, \\ Nguyễn Thành Như Ý, Đặng Thanh Xuân
}

Ngày 16 Tháng 02 năm 2022

Preprint DOI: https://osf.io/5726x

\section{BỐI CẢNH}

Từ cuối năm 2019, đại dịch COVID-19 xảy ra trên toàn cầu, tạo nên cuộc khủng hoảng đa chiều, tác động đến nhiều ngành nghề khác nhau, cuộc sống vật chất lẫn tinh thần của con người. Cho tới nay, đại dịch Covid-19 vẫn tiếp tục càn quét khốc liệt, gây nhiều ảnh hưởng tiêu cực chưa từng có tiền lệ với Việt Nam và toàn thế giới (La, 2020; Vuong, Q.H., 2022). 


\section{Hình 1: Tổng số ca mắc và số ca mắc COVID-19 mới tại Việt Nam}

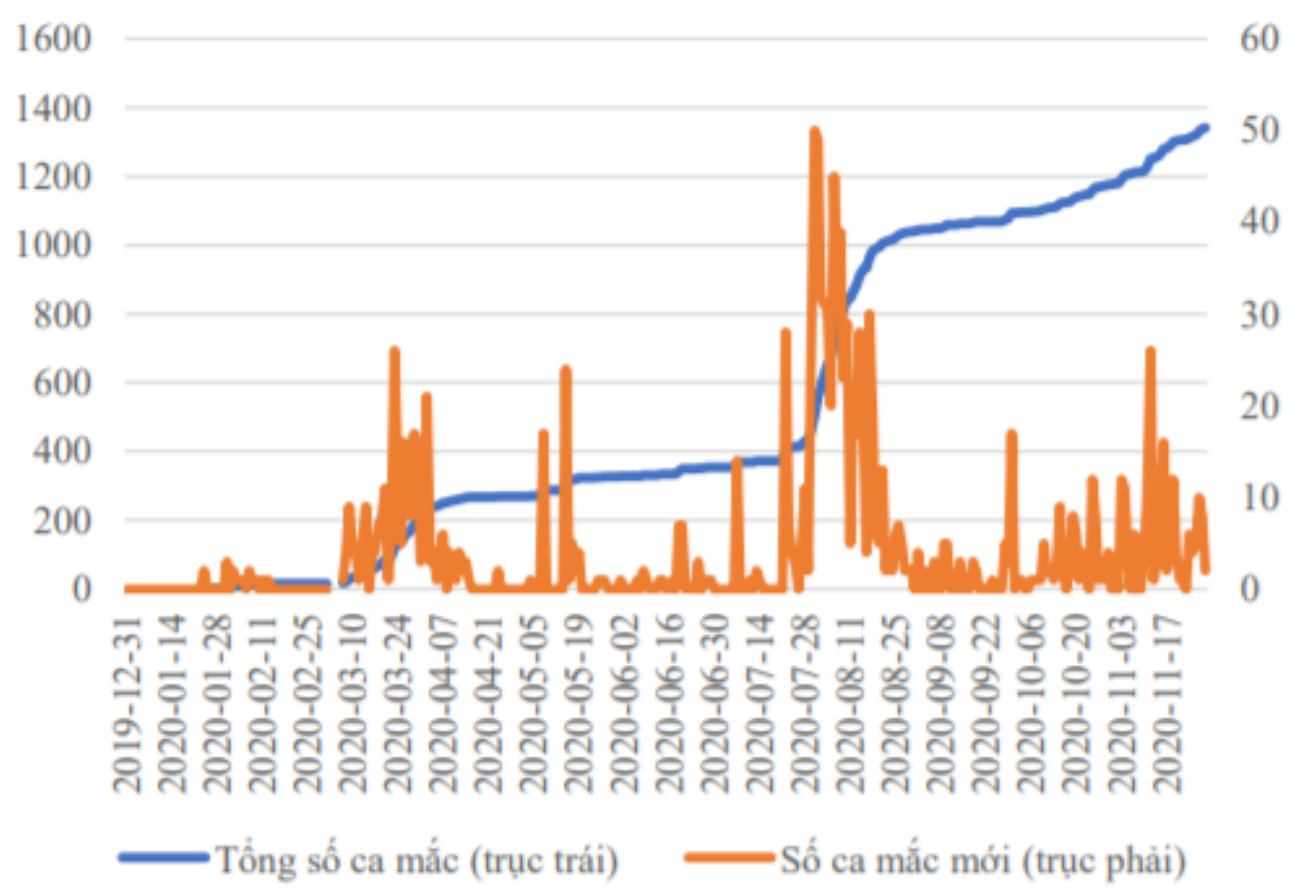

Nguồn: ourworldindata.com

Tính tới ngày 26/12/2021, ngót nghét gần 2 năm từ thời điểm đại dịch bùng phát tại các tỉnh miền Bắc, tổng số ca nhiễm trên cả nước ta là hơn 1,6 triệu ca, trong đó hơn 31 nghìn người không qua khỏi. Trong đó, điển hình là TP Hồ Chí Minh với hơn 500 nghìn ca, Bình Dương gần 300 nghìn ca, Đồng Nai hơn 96 nghìn ca, Hà Nội hơn 36 nghìn ca (Giang, 2021). Không từ ngữ nào có thể diễn tả hết những đau thương, mất mát mà từng cá nhân, mỗi gia đình và cả dân tộc ta đang phải gánh chịu. Những chiến sĩ xông pha không ngày trở về, đội ngũ y tế hi sinh chiến đấu với virus, bao em bé rơi vào cảnh mồ côi, mọi mặt của đời sống bị ảnh hưởng trầm trọng, từ kinh tế, văn xoá, xã hội, giao thông, giải trí, du lịch... Trong đợt dịch thứ 4 bùng phát từ ngày 27/4/2021, biến thể virus Delta lây lan rất nhanh và mạnh, tại nhiều tỉnh, thành phố lớn có mật độ dân cư cao, là đầu mối giao thông huyết mạch của cả nước, nhiều khu công nghiệp trọng điểm. Dịch bệnh không lây theo chuỗi từ người này sang người kia mà theo lây theo chùm ca bệnh, F0 tăng theo cấp số nhân.

Trước tình hình đó, để khống chế sự lây lan ngày một rộng hơn của đại dịch, ngày 31/3/2020, Thủ tướng Chính phủ ban hành Chỉ thị số 16/CT-TTg về các biện pháp cấp bách phòng, 
chống dịch COVID-19 với nhiều nội dung nhằm thắt chặt và kiểm soát mọi hoạt động của người dân.

\section{Chỉ thị 16 ảnh hưởng đến nền kinh tế Việt Nam như thế nào ?}

Theo lời ông Nguyễn Thành Phong (nguyên là Chủ tịch UBND Thành phố Hồ Chí Minh, đương là Phó trưởng Ban Kinh Tế Trung Ương CSVN), tổng thiệt hại do đại dịch Covid mang đến cho nền kinh tế Việt Nam năm 2020-2021 có thể ước lượng tầm 37 tỷ USD - 1 con số không hề nhỏ. Vậy kinh tế Việt Nam đã phải chịu những ảnh hưởng, thiệt hại như thế nào?

Theo thống kê: GDP của cả nước năm 2020 là 2,91\% - đây là con số GDP thấp nhất của kinh tế Việt Nam từ năm 2011-2020. Đặc biệt, khi làn sóng covid lần thứ 4 ập đến kéo dài đã tiếp tục để lại những tác động tiêu cực cho nền kinh tế nước ta. Lần đầu tiên kể từ khi tính GDP theo quý, Việt Nam ta có một quý tăng trưởng âm: quý 3 năm 2021, GDP đã giảm 6,17. Đây cũng là lần đầu phía Nam có 19 tỉnh thành (bao phủ hơn 44\% GDP cả nước) mà có tới 18 tỉnh thành cùng tăng trưởng âm. Thiệt hại nặng nề nhất là kinh tế của TP Hồ Chí Minh GDP giảm tới 24,39\%. Theo như thống kê thì GDP của các ngành kinh tế quan trọng đều có xu hướng giảm mạnh, các trụ cột tăng trưởng kinh tế cũng đang lung lay trong thời điểm ấy: công nghiệp chế biến giảm 9,2\%, xây dưng giảm 11,4\%, thuoong mại giảm 19,9\%, vận tải giảm 21,1\%, thủy sản âm 4,9\%, xuất khẩu giảm 5,8\% (Nguyên, 2021). Mặc dù 8 tháng đầu năm vẫn tăng hơn 20\% nhưng các khối doanh nghiệp trong nước đã nhập siêu lên đến hơn 20 tỉ USD, trong khi đó khối doanh nghiệp FDI xuất siêu hơn 16,7 tỉ USD. So với năm 2020, cán cân thương mại đang bị thâm hụt con số lên đến hơn 3,71 tỉ USD.

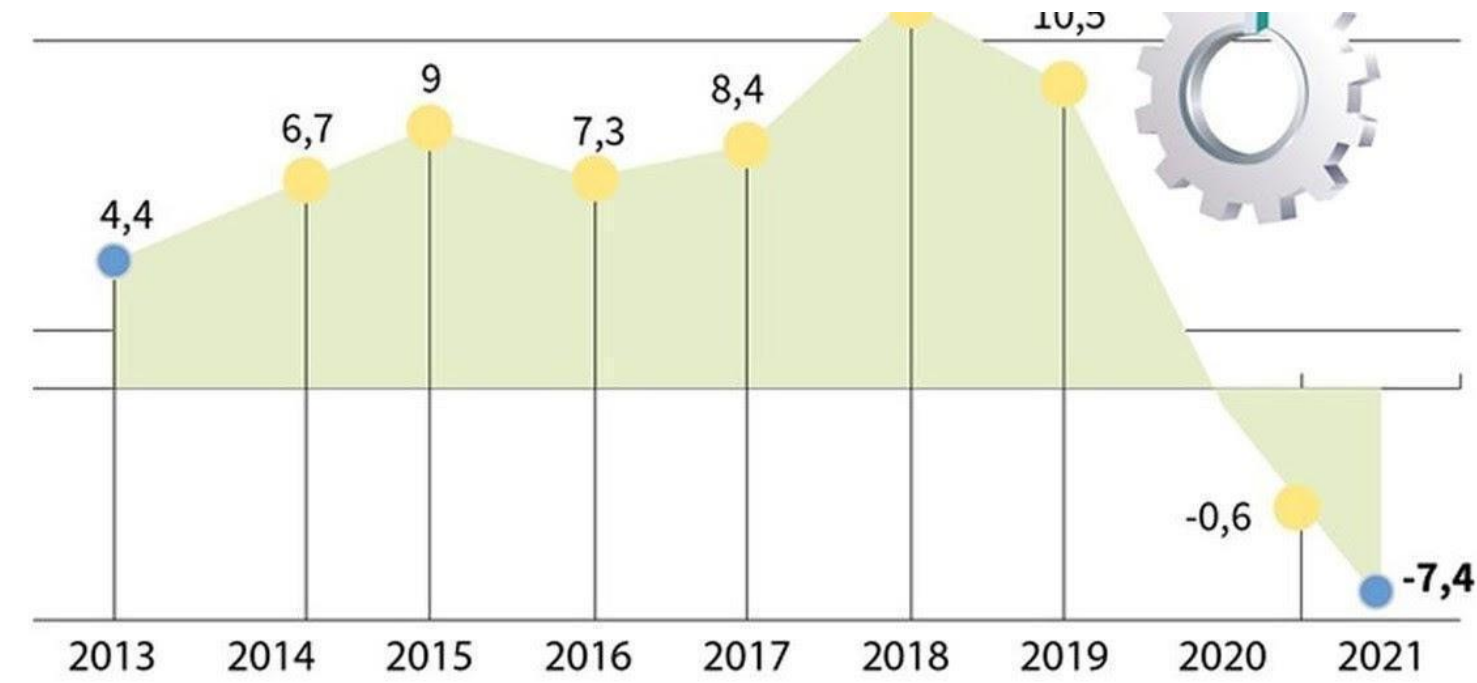

Nguồn: Tổng cục Thống kê

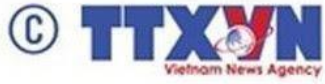

https://infographics.vn

Chỉ số sản xuất công nghiệp tháng 8 đã giảm mạnh -7,4\% so với cùng kì năm 2020, hiện tương chưa tùng có kể tù năm 2013. 
https://photo-cms-viettimes.zadn.vn/w1200/Uploaded/2022/ecfzyrrtlyr/2021_09_20/vnapotal-8-thang-nam-2021-chi-so-san-xuat-cong-nghiep-tang-56-04-1493.jpg

Tình trạng hoạt động của các doanh nghiệp do giãn cách cũng không hề khả quan: tình trạng giải thể, tạm ngừng hoạt động, đóng cửa doanh nghiệp xảy ra với tỉ lệ cao, rất nhiều doanh nghiệp trong tình trạng "ngắc ngoải"

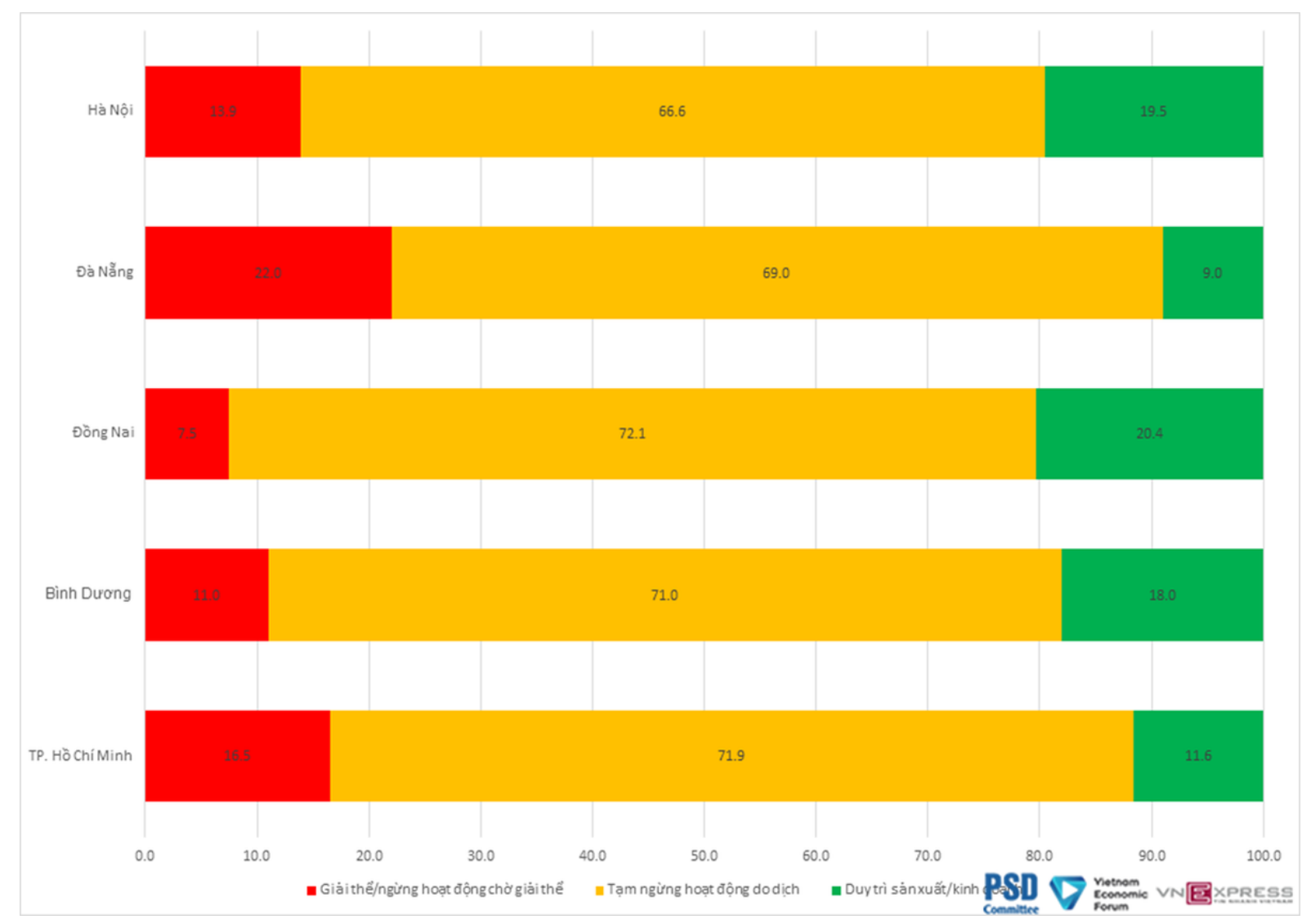

Tình trạng hoạt động của các doanh nghiệp phân theo tùng tỉnh/thành phố tại 5 tỉnh thành có quy mô kinh tế lớn.

https://photo-cms-viettimes.zadn.vn/w1200/Uploaded/2022/ecfzyrrtlyr/2021_09_20/suckhoe-doanh-nghiep-4491.png

Khoảng $40 \%$ số doanh nghiệp cho biết tình hình tài chính vô cùng căng thẳng, chỉ đủ dòng tiền để duy trì hoạt động dưới một tháng; $46 \%$ cho rằng chỉ có thể duy trì trong khoảng thời gian ngắn, song cũng không thể trên 3 tháng.

Còn theo Cục Quản lý Đăng ký kinh doanh (Bộ Kế hoạch và Đầu tư), từ đầu năm đến nay, có 81.584 doanh nghiệp thành lập mới nhưng có tới 85.508 doanh nghiệp rút lui khỏi thị trường, 
tăng 24,2\% so cùng kỳ năm trước; trong đó, 50,5\% là tạm ngừng kinh doanh, còn lại đang làm thủ tục giải thể hoặc đã hoàn thành thủ tục phá sản.

Đối với các ngành, Du lịch là một trong những ngành ảnh hưởng nặng nề nhất do dịch COVID-19 đem lại, tác động với các ngành chế biến chế tạo không đồng nhất. Ví dụ, ngành hải sản đã phục hồi khá nhanh chóng từ cuối tháng 4/2020, theo báo cáo của VASEP. Ngành chế biến hải sản với đa số là các DN tư nhân trong nước đã giảm sự phụ thuộc vào nguồn nguyên liệu nhập khẩu và phát triển các thị trường xuất khẩu đa dạng. Nhờ việc ổn định dịch kịp thời ở Việt Nam mà ngành hải sản có được ưu thế nhất định trong việc mở rộng phát triển thị phần so với các nước đối thủ trong khu vực Châu Á như Ân độ, Thái Lan, và Philippine hiện vẫn còn bị ảnh hưởng của đại dịch (VASEP 2020). Trong ngành điện tử xuất hiện hai xu hướng: trong khi nhóm ngành sản xuất máy tính, điện thoại và linh kiện điện thoại tăng trưởng nhẹ trong Qúy $\mathrm{I} / 2020$ thì các sản phẩm tiêu dùng điện tử khác như camera, máy in, linh kiện điện tử cho ô tô và máy móc lại sụt giảm mạnh 


\begin{tabular}{|c|c|c|c|}
\hline Ngành & Tác động kinh tế & Số NLĐ bị ånh hưởng & $\begin{array}{l}\text { Nguồn và quy mô mắu } \\
\text { kháo sát }\end{array}$ \\
\hline Dệt may & $\begin{array}{l}\text { - } 74 \% \text { DN bị sụt giảm từ } 30 \% \\
\text { đơn hàng trở lên }\end{array}$ & $\begin{array}{l}70 \% \text { DN đă cho LĐ } \\
\text { nghi việc (tháng } \\
\text { 3/2020) }\end{array}$ & VITAS - 200 DN \\
\hline $\begin{array}{l}\text { Chế biến } \\
\text { gỗ }\end{array}$ & $\begin{array}{l}\text { - } 58 \% \text { DN tạm ngừng hoạt } \\
\text { động một phàn hoặc toàn bộ } \\
\text { - } 35 \% \text { DN dự kiến sẽ ngừng } \\
\text { hoạt động một phàn hoặc } \\
\text { toàn bộ }\end{array}$ & $\begin{array}{l}45 \% \text { NLĐ phải nghỉ } \\
\text { việc }\end{array}$ & $\begin{array}{l}\text { Viforest/HAWABIFA - } \\
120 \text { DN trong nước }\end{array}$ \\
\hline $\begin{array}{l}\text { Chế biến } \\
\text { hải sản }\end{array}$ & $\begin{array}{l}\text { - Xuá́t khấu Qứ I/2020 giảm } \\
8 \% \text { so với cùng kỳ } 2019 \\
\text { - } 30 \% \text { đơn hàng xuát kháu bi } \\
\text { hoãn và } 40 \% \text { bị hửy } \\
\text { - } \quad \text { Bắt đầu phục hồi từ cuối } \\
\text { tháng } 4 / 2020\end{array}$ & $\begin{array}{l}\text { Có thế thiếu lao động } \\
\text { khi ngành phục hời }\end{array}$ & $\begin{array}{l}\text { VASEP Báo cáo thủ } \\
\text { tướng Chính phủ, } \\
\text { tháng } 5 / 2020\end{array}$ \\
\hline Điện tử & $\begin{array}{l}\text { - Xuá́t khắu máy tính, điện } \\
\text { thoại và linh kiện điện thoại } \\
\text { tăng (2-16\%) Quý I/2020 so } \\
\text { với cùng kỳ } 2019 \\
\text { - Xuát khắu các sản phắm } \\
\text { khác (máy in, camera, linh } \\
\text { kiện) giảm 52\% Quý I } 2020 \\
\text { so với cùng kỳ } 2019\end{array}$ & $\mathrm{~N} / \mathrm{A}$ & $\begin{array}{l}\text { Tóng cục thống kê, } \\
\text { Báo cáo tình hình kinh } \\
\text { tế - xã hội Quý I/2020 }\end{array}$ \\
\hline Du lịch & $\begin{array}{l}\text { - } 71 \% \text { DN giảm doanh thu trên } \\
30 \% \text { so với cùng kỳ } 2019 \text { và } \\
77 \% \text { cho răng doanh thu sẽ } \\
\text { giám trên } 80 \% \text { vào Quý } \\
\text { II/2020 }\end{array}$ & $\begin{array}{l}\text { 18\% DN cho tắt cả LĐ } \\
\text { nghi việc; } 48 \% \text { cho } \\
\text { nghi việc } 50-80 \% \text { LĐ }\end{array}$ & $\begin{array}{l}\text { Ban Tư vắn Du lịch } \\
\text { (TAB) và VnExpress, } \\
394 \mathrm{DN}\end{array}$ \\
\hline
\end{tabular}

Bảng tóm tắt các khảo sát tác động của COVID-19 đối với các ngành

Nguồn: (TS Đỗ Quỳnh Chi, 2020) 


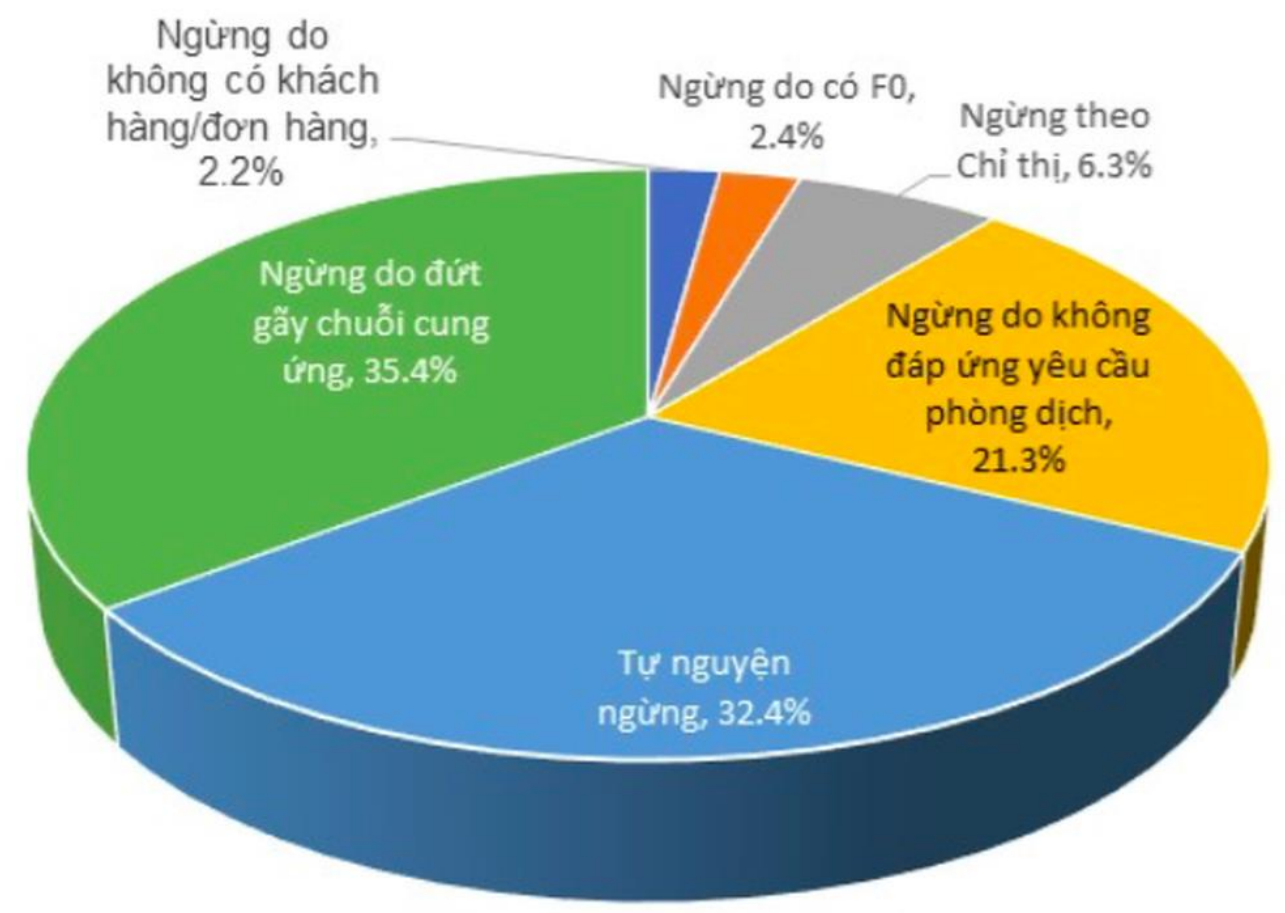

Lý do doanh nghiệp phải đóng cưa trong bối cảnh dịch bùng phát.

https://photo-cms-viettimes.zadn.vn/w1200/Uploaded/2022/ecfzyrrtlyr/2021_09_20/ly-dodoanh-nghiep-dong-cua-7912-1631003383-860x0-5701.png

Bên cạnh đó, đối với yếu tố cầu, dịch bệnh COVID-19 cùng với việc thực hiện biện pháp giãn cách xã hội cần thiết, bắt buộc theo Chỉ thị số 16/CT-TTg, ngày 31-3-2020, của Thủ tướng Chính phủ, "Về thực hiện các biện pháp cấp bách phòng, chống dịch COVID-19" làm tiêu dùng trong nước sụt giảm mạnh. Trong khi đó, các nền kinh tế lớn (Mỹ, Trung Quốc, EU, Nhật Bản, Hàn Quốc) cũng chịu ảnh hưởng lớn bởi dịch bệnh và thực hiện các biện pháp giãn cách xã hội dẫn đến tăng trưởng kinh tế suy giảm, kéo theo sự sụt giảm về cầu nhập khẩu, trong đó có hàng hóa nhập khẩu từ Việt Nam.

Theo số liệu của Tổng cục Thống kê, trong 6 tháng đầu năm 2020, tổng mức bán lẻ hàng hóa và doanh thu dịch vụ tiêu dùng giảm $0,8 \%$ so với cùng kỳ năm 2019 và nếu loại trừ yếu tố giá thì còn giảm mạnh hơn, ở mức 5,3\% (cùng kỳ năm 2019 tăng 8,5\%). Trong đó, doanh thu bán lẻ hàng hóa 6 tháng đầu năm 2020 tăng 3,4\% so với cùng kỳ năm 2019 (Tổng cục thống kê Việt Nam, 2020). Những mặt hàng thiết yếu đối với cuộc sống như lương thực, thực phẩm, đồ dùng, dụng cụ, trang thiết bị gia đình tăng; nhưng những mặt hàng như may mặc, phương tiện đi lại, văn hóa phẩm, giáo dục... chịu ảnh hưởng nặng nề bởi các biện pháp giãn cách xã hội có tốc độ giảm.

Cũng trong 6 tháng đầu năm 2020, doanh thu dịch vụ lưu trú, ăn uống giảm tới 18,1\% so với cùng kỳ năm 2019; doanh thu du lịch lữ hành giảm tới 53,2\% - đây là lĩnh vực chịu tác động 
nghiêm trọng nhất bởi dịch bệnh COVID-19 và từ việc thực hiện các biện pháp giãn cách xã hội. (Tổng cục thống kê Việt Nam, 2020)

Nhìn chung, do ảnh hương đại dịch COVID-19, cầu của nền kinh tế (tiêu dùng, đầu tu, xuất khẩu) bị sụt giảm, tù đó làm suy giảm hoạt động sản xuất và tăng trưởng của nền kinh tế. Các biện pháp của Chính phủ đang triển khai hiện nay chủ yếu huớng tới kích thích tổng cầu và phục hồi sản xuất.

Đối với yếu tố cung, đại dịch COVID-19 làm đứt gãy chuỗi cung ứng đầu vào và lao động. Chẳng hạn, trong ngành công nghiệp ô-tô, do linh kiện đầu vào khan hiếm cùng với thực hiện giãn cách xã hội nên các doanh nghiệp sản xuất ô-tô trong nước như Honda, Nissan, Toyota, Ford, Hyundai... phải tuyên bố tạm dừng sản xuất, chỉ đến khi thời kỳ giãn cách xã hội kết thúc và chuỗi cung ứng được kết nối trở lại, các doanh nghiệp sản xuất ô-tô mới quay trở lại hoạt động.

9 tháng đầu năm 2021, dịch Covid-19 ảnh hưởng tiêu cực đến kinh tế Việt Nam. Đặc biệt, đợt dịch kéo dài từ tháng 7 đến nay tại các tỉnh Đông Nam Bộ, Đồng bằng sông Cửu Long và Hà Nội phải thực hiện giãn cách xã hội theo Chỉ thị 16 trong thời gian dài đã ảnh hưởng đến kết quả tăng trưởng kinh tế (GDP) cả nước, theo đó, GDP quý III/2021 có mức giảm sâu nhất kể từ khi tính và công bố GDP theo quý tại Việt Nam.

Trong khâu lưu thông, vận chuyển hàng hóa giữa các tỉnh, thành phố bị hạn chế tối đa, thậm trí mọi loại hình vận tải phải ngưng hoạt động tại các tỉnh giãn cách xã hội. Hoạt động nông, lâm nghiệp và thủy sản cũng gặp nhiều khó khăn do không thể lưu thông được hàng hóa nông sản. Thêm vào đó, nhiều doanh nghiệp chế biến lương thực, thực phẩm ngừng thu mua nông sản, doanh nghiệp đóng hàng xuất khẩu không hoạt động hoặc hoạt động cầm chừng khiến nhiều nông sản (lúa, hoa quả các loại) không thể xuất khẩu. Không thể tiêu thụ sản phẩm do ách tắc khâu lưu thông, chi phí vận tải, bảo quản tăng cao nên giá thu mua hàng nông sản giảm mạnh nhưng giá bán tới tay người tiêu dùng ở mức cao do chi phí lưu thông tăng cao. Tùy vào tình hình dịch bệnh, các địa phương đã thực hiện giãn cách xã hội nghiêm ngặt theo Chỉ thị 16+, Chỉ thị 16 hoặc Chỉ thị 15 dẫn đến các hoạt động thương mại, lưu trú ăn uống rơi vào tình trạng bế tắc. Hầu hết các cơ sở kinh tế trong lĩnh vực này phải đóng cửa; chỉ một số cơ sở lưu trú được phép cung cấp dịch vụ cho người bị cách ly có thể hoạt động cầm chừng để duy trì không rơi vào tình trạng phá sản.

Covid-19 diễn biến phức tạp dẫn đến việc phải giãn cách xã hội. Theo thống kê có hơn 1,7 triệu người trong độ tuổi lao động đã thất nghiệp trong quý 3 (tăng khoảng nửa triệu so với quý 2). Tỷ lẹ thất nghiệp gia tăng-con số lên đến 3,98\%, cao nhất trong suốt thập kỷ qua và đã vượt xa tỷ lệ thất nghiệp trong nhũng giai đoạn khó khăn khác của nền kinh tế (Nguyên, 2021). Điều này đã trở thành nguyên nhân chính dẫn đến những thiệt hại lớn cho nền kinh tế nước ta. Các chuyên gia cảnh báo rằng nếu Việt Nam không nhanh chóng kiềm chế được dịch bệnh và có lộ trình rõ ràng để mở cửa lại nền kinh tế thì những tổn thất sẽ vượt quá nguỡng có thể khôi phuc được (Minh, 2021). Đứng trước nguy cơ nền kinh tế Việt Nam ngày càng chuyển biến xấu hơn, thậm chí sẽ phải mất 1 khoảng thời gian vô cùng dài để có thể khôi phục nền kinh tế, Chính phủ Việt Nam đã đưa ra quyết định: Tạm dìng áp dụng chỉ thị số 16. 


\section{TÀI LIỆU THAM KHẢO}

Giang, T. (2021). Ngày 26/12: Hà Nội thêm 1.887 ca mắc COVID-19, có 794 ca cộng đồng. Vietnamplus. https://www.vietnamplus.vn/ngay-2612-ha-noi-them-1887-ca-mac-covid19co-794-ca-cong-dong/765128.amp?fbclid=IwAR37jMRpvFOlGOU1G9g4mJ_ZoeIRgtsIf6NFcC3Adg1A13-Xh2kNVhzTBI

La, V. P. et al. (2020). Policy response, social media and science journalism for the sustainability of the public health system amid the COVID-19 outbreak: The vietnam lessons. Sustainability (Switzerland), 12(7). https://doi.org/10.3390/su12072931

Minh, T. (2021). Kinh tế Việt Nam trước "cú sốc" Covid-19. VietTimes. https://viettimes.vn/kinh-te-viet-nam-truoc-cu-soc-covid-19-post150512.html

Nguyên, T. (2021). Một năm kinh tế ngấm đòn Covid-19. Báo Mới. https://baomoi.com/motnam-kinh-te-ngam-don-covid-19/c/41306784.epi

Tổng cục thống kê Việt Nam. (2020). BÁO CÁO TìNH HÌNH KINH TÉ - XÃ HỌI QUÝ II VÀ 6 THÁNG NĂM 2020. Tổng Cục Thống Kê. https://www.gso.gov.vn/du-lieu-va-so-lieuthong-ke/2020/06/bao-cao-tinh-hinh-kinh-te-xa-hoi-6-thang-dau-nam2020/?fbclid=IwAR36QeMZKB9DS8MRRaS1WlCFbOpQLLq5lvvx9T742vlfD2vTi3cSi0FDmg

TS Đỗ Quỳnh Chi, T. tâm N. cứu Q. hệ lao động (ERC). (2020). Đánh giá nhanh tác động của đại dịch COVID-19 tới doanh nghiệp và ngườ lao động trong một số ngành kinh tế chính: Úng phó, điều chỉnh và khả năng phục hồi. Tổ Chức Lao Động Quốc Tế.

Vuong, Q.H., et al. (2022). Covid-19 vaccines production and societal immunization under the serendipity-mindsponge-3D knowledge management theory and conceptual framework. Humanities \& Social Sciences Communications, 9, 22. Retrieved from: https://www.nature.com/articles/s41599-022-01034-6 